\title{
Risk variables associated with abnormal calcium, magnesium and phosphate levels among emergency department patients
}

\author{
(abnormal calcium, magnesium and phosphate levels)
}

\author{
David McD Taylor $\mathrm{MD}^{1,2}$ \\ David.Taylor@austin.org.au
}

Patrick A Date $\mathrm{MD}^{1}$

patrick.a.date@gmail.com

Antony Ugoni $\mathrm{MSc}^{3}$

augoni@seek.com.au

Jesse L Smith $\mathrm{MD}^{4}$

jesse.lachlan.smith@gmail.com

William S Spencer $\mathrm{MD}^{5}$

Willsspencer1@gmail.com

Erik J de Tonnerre $\mathrm{MD}^{6}$

edetonnerre@gmail.com

Michael J Yeoh MBBS ${ }^{1}$

Michael.Yeoh@austin.org.au

${ }^{1}$ Austin Hospital, Studley Road, Heidelberg, Victoria, Australia

${ }^{2}$ Department of Medicine, University of Melbourne, Parkville, Victoria, Australia

${ }^{3}$ Centre for Epidemiology and Biostatistics, University of Melbourne, Parkville, Victoria, Australia

${ }^{4}$ Central Gippsland Health, Sale, Victoria, Australia

${ }^{5}$ Alfred Health, Commercial Road, Melbourne, Victoria, Australia

${ }^{6}$ Northern Sydney Local Health District, NSW Health, NSW, Australia

\section{Address for correspondence:}

Professor David Taylor

Emergency Department

Austin Health

PO Box 5555, Heidelberg, Victoria, Australia 3084

David.Taylor@austin.org.au

Phone: +61 394964711

ThiFiaxthe64 G39496a3880ript accepted for publication and has undergone full peer review but has not been through the copyediting, typesetting, pagination and proofreading process, which may lead to differences between this version and the Version of Record. Please cite this article as doi: $10.1111 / 1742-6723.13411$

This article is protected by copyright. All rights reserved. 


\title{
Meetings:
}

This study was presented at the Annual Scientific Meeting of the Australasian College for Emergency Medicine, Perth, Australia (November, 2018) and at the International Conference on Emergency Medicine, Seoul, South Korea (June 2019).

\section{Grants:}

The study was unfunded

\section{Conflicts of Interests:}

The authors acknowledge no conflicts of interest in relation to this study.

Word Count: Abstract 247, Text 2171

\begin{abstract}
Author contribution:
PD and DT developed the protocol for the project that this research was drawn from. DT obtained ethics committee approval. PD, JS, WS, EdeT and MY assisted with collection. AU and DT undertook the data analysis. All authors contributed to results interpretation. All authors contributed to drafting and critical revision of the manuscript. DT supervised the project overall. All authors take responsibility for the manuscript.
\end{abstract}




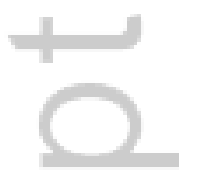




\title{
Risk variables associated with abnormal calcium, magnesium and phosphate levels among emergency department patients
}

\author{
(abnormal calcium, magnesium and phosphate levels)
}

\author{
David McD Taylor $\mathrm{MD}^{1,2}$ \\ David.Taylor@austin.org.au
}

Patrick A Date $\mathrm{MD}^{1}$

patrick.a.date@gmail.com

Antony Ugoni $\mathrm{MSc}^{3}$

augoni@seek.com.au

Jesse L Smith $\mathrm{MD}^{4}$

jesse.lachlan.smith@gmail.com

William S Spencer $\mathrm{MD}^{5}$

Willsspencer1@gmail.com

Erik J de Tonnerre $\mathrm{MD}^{6}$

edetonnerre@gmail.com

Michael J Yeoh MBBS ${ }^{1}$

Michael.Yeoh@austin.org.au

${ }^{1}$ Austin Hospital, Studley Road, Heidelberg, Victoria, Australia

${ }^{2}$ Department of Medicine, University of Melbourne, Parkville, Victoria, Australia

${ }^{3}$ Centre for Epidemiology and Biostatistics, University of Melbourne, Parkville, Victoria, Australia

${ }^{4}$ Central Gippsland Health, Sale, Victoria, Australia

${ }^{5}$ Alfred Health, Commercial Road, Melbourne, Victoria, Australia

${ }^{6}$ Northern Sydney Local Health District, NSW Health, NSW, Australia

Address for correspondence:

Professor David Taylor

Emergency Department

Austin Health

PO Box 5555, Heidelberg, Victoria, Australia 3084

David.Taylor@austin.org.au

This article is protected by copyright. All rights reserved. 
Phone: +61 394964711

Fax: +61 394963380

\section{Meetings:}

This study was presented at the Annual Scientific Meeting of the Australasian College for Emergency Medicine, Perth, Australia (November, 2018) and at the International Conference on Emergency Medicine, Seoul, South Korea (June 2019).

\section{Grants:}

The study was unfunded

\section{Conflicts of Interests:}

The authors acknowledge no conflicts of interest in relation to this study.

Word Count: Abstract 247, Text 2171

\section{Author contribution:}

PD and DT developed the protocol for the project that this research was drawn from. DT obtained ethics committee approval. PD, JS, WS, EdeT and MY assisted with collection. AU and DT undertook the data analysis. All authors contributed to results interpretation. All authors contributed to drafting and critical revision of the manuscript. DT supervised the project overall. All authors take responsibility for the manuscript. 


\title{
Risk variables associated with abnormal calcium, magnesium and phosphate levels among emergency department patients
}

\author{
(Running title: calcium, magnesium and phosphate)
}

\begin{abstract}

\section{Background}

The utility of calcium, magnesium and phosphate measurement in the emergency department (ED) is limited. We aimed to determine clinical risk variables for abnormal levels of these electrolytes in order to inform the development of an ordering guideline.
\end{abstract}

\section{Methods}

We performed a retrospective, observational study of patients who presented to a tertiary referral ED between January and June 2017. Adult patients who had serum calcium, magnesium or phosphate tests completed during their ED stay were included. Presenting symptoms and signs, co-morbidities, medication use and laboratory values were extracted from the medical record. Patients with missing data items were excluded. Logistic regression models determined clinical risk variables associated with low and high levels of each electrolyte.

This article is protected by copyright. All rights reserved. 


\section{Results}

33,120 adults presented during the study period. Of the 1,679 calcium, 1,576 magnesium and 1,511 phosphate tests, 228 (13.6\%), 158 (10.0\%) and 387 (25.6\%) were abnormal, respectively. Significant risk variables $(\mathrm{p}<0.05)$ for abnormal levels were: hypocalcemia - vomiting, perioral numbness, hand/foot spasm, calcium and phosphate supplements and chemotherapy (OR range 5.9-17.3); hypercalcemia female sex, vomiting, polyuria, confusion, hyperparathyroidism, cancer and type 1 diabetes (OR range 2.3-9.7); hypomagnesemia - female sex, proton pump inhibitor use, tacrolimus use, alcohol abuse and type 2 diabetes (OR range 2.2-13.1); hypermagnesemia - lethargy, thiazide use, and chronic kidney disease (OR range 4.34.5); hypophosphatemia - nausea, seizure and glucocorticoid use (OR range 1.7-2.1); and hyperphosphatemia - polyuria, diuretics and chronic kidney disease (OR range 1.9-5.0).

\section{Conclusion}

A range of demographic, co-morbid, medication and clinical variables are associated with abnormal calcium, magnesium and phosphate levels. These findings will inform the development of clinical guidelines to rationalise calcium, magnesium and phosphate testing. Justification may be required for testing patients with no risk variables.

This article is protected by copyright. All rights reserved. 
Keywords: Calcium, Magnesium, Phosphate, Utility, Emergency Health Service, Choosing Wisely

\section{INTRODUCTION}

The Choosing Wisely initiative was introduced in 2012 in order to reduce unnecessary or harmful laboratory and imaging investigations. Its ultimate purpose was to improve patient care and minimise spending on tests and treatments that provide minimal or no patient benefit. ${ }^{1,2}$ Specific focus has been on, amongst other things, the testing of coagulation, blood cultures and prostate specific antigen where not indicated by scientific evidence. . $^{3,4}$

In line with the Choosing Wisely initiative, we undertook an emergency department (ED) research project that aimed to determine how frequently calcium (Ca), magnesium $(\mathrm{Mg})$ and phosphate $\left(\mathrm{PO}_{4}\right)$ tests are ordered and how frequently the tests results change patient management. ${ }^{5}$ We found that $1,716(5.2 \%)$ of 33,120 patients had at least one $\mathrm{Ca}, \mathrm{Mg}$ or $\mathrm{PO}_{4}$ test completed in the ED. 776 (16.2\%) tests were abnormal although only 56 (1.2\%) changed ED management. So, although testing is

This article is protected by copyright. All rights reserved. 
common, the yield of abnormal results is low and patient management is rarely changed. These findings support those of earlier research. ${ }^{6}$

There is a need, therefore, for better targeting of patients most likely to benefit from testing of these electrolytes. The medical literature has numerous reports of a wide range of clinical signs, symptoms, comorbidities and medications that are associated with abnormalities in these electrolytes. However, these reports derive from settings other than the ED. We aimed to determine the variables associated with abnormal Ca, $\mathrm{Mg}$ and $\mathrm{PO}_{4}$ levels within a large cohort of ED patients. The findings will inform the development of guidelines and decision support tools to minimise unnecessary testing of these electrolytes.

This article is protected by copyright. All rights reserved. 


\section{METHODS}

\section{Study Design and Setting}

We undertook a retrospective medical record review of adult patients who had at least one $\mathrm{Ca}, \mathrm{Mg}$ or $\mathrm{PO}_{4}$ test in the ED of a tertiary referral hospital in metropolitan <city>, $<$ country $>$. The ED has a mixed (paediatric and adult) annual census of approximately 90,000 patients. The study was approved by the institution's Human Research Ethics Committee.

\section{Study Population}

Adult patients (aged $\geq 18$ years) presenting to the ED between January 1 and June 30 2017 (inclusive) were included if they had at least one $\mathrm{Ca}, \mathrm{Mg}$ and/or $\mathrm{PO}_{4}$ test ordered and completed (results available to the ED staff) during their time in the ED. Patients with missing data were excluded. The patient population for this study was the same as that analysed in our descriptive study. ${ }^{5}$

\section{Study Protocol}

Patients were identified electronically using the ED electronic medical record system, Cerner FirstNet ${ }^{\circledR}$ (version 2015.01.17, Cerner Corporation, North Kansas City, Missouri, USA). The system allows for screening and identification of patients who underwent a range of ED investigations.

This article is protected by copyright. All rights reserved. 
An Excel ${ }^{\circledR}$ spreadsheet was designed, trialled and revised specifically for the project. Electronic data were downloaded and entered directly into the study spreadsheet: name, age, gender, presentation date, triage category and pain scores, presenting complaint (coded and descriptive), corrected $\mathrm{Ca}, \mathrm{Mg}$ and/or $\mathrm{PO}_{4}$ levels, and discharge destination. ED discharge summaries were then accessed to extract presenting symptoms and signs, co-morbidities, current medications and changes to ED management. Scanned electronic records were also accessed to clarify patient presenting symptoms and/or past medical history. Interrogation was particularly detailed in order to identify predetermined symptoms and signs, co-morbidities and medications known to be associated with abnormalities in Ca, $\mathrm{Mg}$ and $\mathrm{PO}_{4}$ levels (see Appendix).

Reference ranges for pathology tests were obtained from the institution's pathology department. The reference ranges for corrected $\mathrm{Ca}, \mathrm{Mg}$ and $\mathrm{PO}_{4}$ levels were 2.15-2.55 $\mathrm{mmol} / \mathrm{L}, 0.66-1.07 \mathrm{mmol} / \mathrm{L}$ and 0.87-1.45 mmol/L, respectively. Values outside of these ranges were deemed to be abnormal. Unique time-stamps for pathology tests were compared with the most accurate time-of-discharge reported for each patient who was transferred to the ward from ED. Patients who were discharged home or to the short stay unit (SSU) were assumed to have had their test completed in the ED prior to transfer.

All medical record reviews were then undertaken by the principal investigator (PD). 
Following data collection, 85 (5\%) patients were randomly selected and their data rechecked for accuracy of data extract and entry. No systemic data extraction errors were identified.

\section{Key Outcome Measures}

The primary study outcome was clinical variables associated with abnormal (high or low) $\mathrm{Ca}, \mathrm{Mg}$ and/or $\mathrm{PO}_{4}$ levels.

\section{Data Analysis}

In our descriptive study ${ }^{5}, 1716$ patients who had a Ca, $\mathrm{Mg}$ or $\mathrm{PO}_{4}$ test completed in the ED were enrolled. We used the same patient population for this study. When comparing two patient subgroups (e.g. with/without a potential risk factor for an electrolyte abnormality), a clinically significant difference in the proportions of patients observed to have the outcome of interest (e.g. electrolyte abnormality) was deemed to be $5 \%$ (e.g. $6 \%$ versus $1 \%$ ). Given these proportions and a patient ratio of 1:10 (with/without a risk factor), the study had a power of 0.91 to demonstrate a difference between the two subgroups (alpha 0.05, 2-sided).

Patients were separated into nine subgroups: normal/low/high for $\mathrm{Ca} / \mathrm{Mg} / \mathrm{PO}_{4}$. For each electrolyte, patients in the low and high level subgroups were compared with

This article is protected by copyright. All rights reserved. 
patients in the normal/high and normal/low level subgroups, respectively, using univariate analyses (Odds Ratio [OR], 95\% confidence intervals [95\%CI]). The subgroups were compared across a range of variables including those previously reported as risk factors for high/low $\mathrm{Ca}, \mathrm{Mg}$ or PO4 levels: demographics, signs and symptoms, co-morbidities and usual medication use (see Appendix).

The range of potential risk factors was extensive $(n=66)$ and identical for the univariate analysis of each electrolyte, despite some variables not known to have an association with certain electrolyte abnormalities. Hence, only those variables found to have some association with an abnormal electrolyte level $(\mathrm{p}<0.10)$ were entered into the logistic regression models to further analyse the associations. Intercooled Stata 6.0 for Windows 98/95/NT (Stata Corporation, College Station, Texas, USA) was used for all analyses. The level of significance was $\mathrm{p}<0.05$.

The study was unfunded.

This article is protected by copyright. All rights reserved. 


\section{RESULTS}

Over the study period, 33,120 adult patients presented to the ED. Of these, 1,716 (5.2\%) patients met the study entrance criteria. These patients had a mean (standard deviation) age of 64 (20.1) years and 810 (47.2\%) were male.

There were a total of 4,776 individual electrolyte tests completed while the patients were in the $\mathrm{ED}\left(1,683 \mathrm{Ca}, 1,579 \mathrm{Mg}\right.$ and 1,514 $\mathrm{PO}_{4}$ tests). Small numbers of patients (4, 3 and 3, respectively) were not included in the regression models due to a missing data item. Hence, 1,679 $\mathrm{Ca}, 1,576 \mathrm{Mg}$ and 1,511 $\mathrm{PO}_{4}$ tests were analysed. Of these, 25 (1.5\%) and 203 (12.1\%) Ca levels were low and high, respectively; 128 (8.1\%) and 30 (1.9\%) Mg levels were low and high, respectively; 224 (14.8\%) and 163 (10.8\%) $\mathrm{PO}_{4}$ levels were low and high, respectively.

Variables associated with low and high Ca levels are reported in Tables 1 and 2, respectively. Low levels were associated with vomiting, perioral numbness, hand or foot spasm, Ca and $\mathrm{PO}_{4}$ supplement use, and chemotherapy $(\mathrm{p}<0.05)$. High levels were associated with female sex, vomiting, polyuria, confusion, hyperparathyroidism, cancer and type 1 diabetes $(\mathrm{p}<0.05)$. Hypothyroidism was a significant protective factor against high levels.

This article is protected by copyright. All rights reserved. 
Variables associated with low and high Mg levels are reported in Tables 3 and 4, respectively. Low levels were associated with female sex, proton pump inhibitor use, tacrolimus use, alcohol abuse and type 2 diabetes $(\mathrm{p}<0.05)$. High levels were associated with lethargy, thiazide use, and chronic kidney disease $(\mathrm{p}<0.05)$. Female sex was a significant protective factor against high levels.

Variables associated with low and high $\mathrm{PO}_{4}$ levels are reported in Tables 5 and 6, respectively. Low levels were associated with nausea, seizure and glucocorticoid use $(\mathrm{p}<0.05)$. Female sex and diuretics were significant protective factors. High levels were associated with polyuria, diuretics and chronic kidney disease $(\mathrm{p}<0.05)$. Palpitations was a significant protective factor against high levels. 


\section{DISCUSSION}

Our findings indicate that $\mathrm{Ca}, \mathrm{Mg}$ and $\mathrm{PO}_{4}$ testing is commonly undertaken in the ED and that small proportions of patients have abnormal levels. Moreover, we have reported that, in the same patient population, only $1.2 \%$ of all tests resulted in a management change. ${ }^{5}$ Arguably, the reason for testing is to identify patients at risk from electrolyte abnormalities and who need treatment in the ED or soon thereafter. It is clear, therefore, that testing for these electrolytes needs to be rationalised.

This study has determined risk variables associated with abnormal $\mathrm{Ca}, \mathrm{Mg}$ and $\mathrm{PO}_{4}$ levels in a large cohort of ED patients. The important risk variables associated with an abnormality are summarised in the Box. These variables will inform the development of clinical guidelines designed to better target patients at risk of a $\mathrm{Ca}, \mathrm{Mg}$ or $\mathrm{PO}_{4}$ abnormalities. For any given patient, an absence of these risk variables may require $\mathrm{Ca}, \mathrm{Mg}$ or $\mathrm{PO}_{4}$ testing to be otherwise justified.

Some variables found to be associated with an electrolyte abnormality have not been included in the Box. These comprise protective variables and those that are common and that have relatively small effect sizes e.g. females (OR 1.6 and 1.9).

Risk variables for $\mathrm{Ca}, \mathrm{Mg}$ and $\mathrm{PO}_{4}$ abnormalities have been investigated in a range of patient populations and in number of settings. To our knowledge, this is the first study 
to investigate this issue in the ED. Overall, our findings are consistent with those of other studies. Hypercalcaemia has commonly been reported in malignancy and hyperparathyroidism. ${ }^{7-10}$ Hypocalcaemia is commonly associated with paraesthesias. ${ }^{7,8}$ Vomiting, confusion and lethargy have also been associated with Ca abnormalities. ${ }^{7,8,11}$ Cancer, chronic kidney disease, diabetes, and alcoholism have each been associated with $\mathrm{Ca}, \mathrm{Mg}$ and $\mathrm{PO}_{4}$ abnormalities. ${ }^{6,9,10,12}$ Medications, including Vitamin D, proton pump inhibitors and glucocorticoids have been associated with hypercalcaemia, hypomagnesaemia and hypophosphataemia, respectively. ${ }^{7,13}$ Although we did not find a significant association between vitamin D and any electrolyte abnormality, there were trends towards some associations (ORs $1.3,1.4)$

This study's findings provide scope and guidance for future research. Firstly, intervention initiatives are indicated to reduce over-investigation of $\mathrm{Ca}, \mathrm{Mg}$ and $\mathrm{PO}_{4}$ levels. In the first instance, this may include ED physician education with regular monitoring and feedback on electrolyte testing. There could also be uncoupling of electronic investigation care sets, where groups of electrolytes are routinely ordered together for specific presenting complaints (e.g. jaundice). Uncoupling would require a specific order for each electrolyte. Secondly, the findings of this study need to be reproduced in a larger, multi-center study, perhaps with the inclusion of additional potential risk variables. This would add external validity and would help refine the important variables that are indications for testing. Thirdly, a clinical guideline is 
recommended, based upon the multi-center study findings, to help ED physicians better target their electrolyte testing. Finally, once implemented, this clinical guideline should be evaluated prospectively for a range of important endpoints: numbers of tests done, cost savings and adverse patient outcomes consequent upon fewer tests being undertaken.

\section{LIMITATIONS}

This study has several limitations. Selection bias is unlikely as electronic screening was employed to identify all eligible patients, the study period was extensive and very few patients were excluded. However, as a single-centered, observational study, its external validity may be questionable.

We did not examine a number of very uncommon variables previously demonstrated to be associated with $\mathrm{Ca}, \mathrm{Mg}$ or $\mathrm{PO}_{4}$ abnormalities e.g. granulomatous disease, immobilisation, inherited renal tube defects and tissue breakdown. ${ }^{13-15}$ Therefore, although this study of risk variables is incomplete, the most commonly reported risks have been included. Furthermore, it is unlikely that future studies would have sufficient power to adequately examine such uncommon conditions.

This article is protected by copyright. All rights reserved. 
Data downloaded electronically were likely to be accurate although, in small number of cases, data were incomplete. The existence of risk factors for some patients would not be known if they were not recorded in the medical record by the treating clinician. Hence, the numbers of patients with risk variables may have been under-estimated. During the manual medical record review, some documented data items may have been missed by the data extractor. However, the data quality assurance exercise revealed no irregularities.

We defined a low or high electrolyte level as one being outside of the normal laboratory range. Levels just outside of the range are likely to be of no clinical significance. Examination of the association between risk variables and levels well outside the normal range may have been more robust and clinically useful.

Some risk variables had large and significant effect sizes (ORs). However, the small numbers of patients with some of these risk variables (e.g. paraesthesia and hypocalcaemia) may have biased the findings. This may have led to inaccuracy in the observed association between some risk factors and electrolyte levels. 
Calcium, magnesium and phosphate testing

\section{CONCLUSION}

Calcium, $\mathrm{Mg}$ and $\mathrm{PO}_{4}$ testing is commonly undertaken in the ED setting. However, only small proportions of tests reveal abnormalities. A range of demographic, clinical, medication, co-morbid variables are associated with abnormal levels of these electrolytes. The presence of one or more of these variables will flag a patient at potential risk and may inform a decision to investigate. Large multi-center studies are recommended to better define the nature and importance of risk variables. The findings will inform the development of evidence-based clinical guidelines in an endeavour to rationalise testing of these electrolytes. For patients without any risk variables, $\mathrm{Ca}, \mathrm{Mg}$ and $\mathrm{PO}_{4}$ testing may need to be otherwise justified.

This article is protected by copyright. All rights reserved. 
ACKNOWLEDGEMENTS

Nil 


\section{REFERENCES}

1. Levinson W, Kallewaard M, Bhatia RS, Wolfson D, Short S, Kerr EA. 'Choosing Wisely': a growing international campaign. BMJ Qual Saf 2015;24:167-74.

2. Lindner RA. Choosing Wisely Australia: changing behaviour in health care. Med J Aust 2018;208:105-6.

3. Sah S, Elias P, Ariely D. Investigation momentum: the relentless pursuit to resolve uncertainty. JAMA Intern Med 2013;173:932-3.

4. National Prescribing Service MedicineWise. Choosing Wisely Australia. Available from: http://www.choosingwisely.org.au/home (accessed September 10, 2019)

5. Date PA, Smith LJ, Spencer WS, de Tonnerre EJ, Yeoh M, Taylor DMcD. Utility of calcium, magnesium and phosphate testing in the emergency department.

Emerg Med Australias Published on line ahead of print June 3, 2019. doi: 10.1111/1742-

6723.13332

6. Rose WD, Martin JE, Abraham FM, Jackson RL, Williams JM, Gunel E. Calcium, magnesium, and phosphorus: emergency department testing yield. Acad Emerg Med 1997;4:559-63.

7. Chang WT, Radin B, McCurdy MT. Calcium, magnesium, and phosphate abnormalities in the emergency department. Emerg Med Clin North Am. 2014;32:349-66.

8. Bushinsky DA, Monk RD. Calcium. Lancet 1998;352:306-11.

9. Lindner G, Felber R, Schwarz C et al. Hypercalcemia in the ED: prevalence, etiology, and outcome. Am J Emerg Med 2013;31:657-60. 
10. Lee CT, Yang CC, Lam KK, Kung CT, Tsai CJ, Chen HC. Hypercalcemia in the emergency department. Am J Med Sci 2006;331:119-23.

11. Weisinger JR, Bellorin-Font E. Magnesium and phosphorus. Lancet 1998;352:391-6.

12. Stalnikowicz R. The significance of routine serum magnesium determination in the ED. Am J Emerg Med 2003;21:444-7.

13. Lindner G, Funk GC, Leichtle AB et al. Impact of proton pump inhibitor use on magnesium homoeostasis: a cross-sectional study in a tertiary emergency department. Int J Clin Pract 2014;68:1352-7.

14. Shiber JR, Mattu A. Serum phosphate abnormalities in the emergency department. J Emerg Med 2002;23:395-400.

15. Silverberg SJ, Walker MD, Bilezikian JP. Asymptomatic primary hyperparathyroidism. J Clin Densitom 2013;16:14-21 
Table 1. Logistic regression results: Variables associated with a low calcium level

\begin{tabular}{|c|c|c|c|c|c|c|}
\hline \multirow{2}{*}{ risk variable } & & \multicolumn{2}{|c|}{$\begin{array}{c}\text { calcium level low } \\
\quad(n=1679)\end{array}$} & \multirow[b]{2}{*}{ OR } & \multirow[b]{2}{*}{ (95\%CI) } & \multirow[b]{2}{*}{$p$} \\
\hline & & no & yes & & & \\
\hline \multirow[t]{2}{*}{ Vomiting } & no & 1456 & 17 & 1 & & \\
\hline & yes & 198 & 8 & 4.3 & $(1.7,10.9)$ & 0.002 \\
\hline \multirow[t]{2}{*}{ Perioral numbness } & no & 1650 & 24 & 1 & & \\
\hline & yes & 4 & 1 & 17.1 & $(1.3,217.9)$ & 0.03 \\
\hline \multirow[t]{2}{*}{ Hand or foot spasm } & no & 1650 & 23 & 1 & & \\
\hline & yes & 4 & 2 & 11.7 & $(1.2,116.8)$ & 0.04 \\
\hline \multirow[t]{2}{*}{ Paraesthesia } & no & 1606 & 21 & 1 & & \\
\hline & yes & 48 & 4 & 4.1 & $(0.9,17.6)$ & 0.06 \\
\hline \multirow[t]{2}{*}{ Calcium supplement } & no & 1515 & 18 & 1 & & \\
\hline & yes & 139 & 7 & 3.0 & $(1.1,8.3)$ & 0.03 \\
\hline \multirow[t]{2}{*}{ Phosphate supplement } & no & 1645 & 24 & 1 & & \\
\hline & yes & 9 & 1 & 17.3 & $(2.0,153.2)$ & 0.01 \\
\hline \multirow[t]{2}{*}{ Cyclosporine } & no & 1646 & 24 & 1 & & \\
\hline & yes & 8 & 1 & 6.5 & $(0.4,96.3)$ & 0.17 \\
\hline \multirow[t]{2}{*}{ Chemotherapy } & no & 1617 & 23 & 1 & & \\
\hline & yes & 37 & 2 & 5.9 & $(1.2,27.6)$ & 0.02 \\
\hline \multirow[t]{2}{*}{ Hyperparathyroidism } & no & 1643 & 24 & 1 & & \\
\hline & yes & 11 & 1 & 2.8 & $(0.2,43.9)$ & 0.46 \\
\hline \multirow[t]{2}{*}{ Diarrhoea } & no & 1629 & 23 & 1 & & \\
\hline & yes & 25 & 2 & 3.1 & $(0.5,18.3)$ & 0.22 \\
\hline \multirow[t]{2}{*}{ Hypothyroidism } & no & 1629 & 24 & 1 & & \\
\hline & yes & 25 & 1 & 2.8 & $(0.8,10.7)$ & 0.12 \\
\hline
\end{tabular}


Table 2. Logistic regression results: Variables associated with a high calcium level

\begin{tabular}{|c|c|c|c|c|c|c|}
\hline \multirow{2}{*}{ risk variable } & & \multicolumn{2}{|c|}{$\begin{array}{c}\text { calcium level } \\
\text { high }(n=1679)\end{array}$} & \multirow[b]{2}{*}{ OR } & \multirow[b]{2}{*}{$(95 \% \mathrm{CI})$} & \multirow[b]{2}{*}{$\mathrm{p}$} \\
\hline & & no & yes & & & \\
\hline \multirow[t]{4}{*}{ Age, years } & $18-39$ & 230 & 19 & 1 & & \\
\hline & $40-59$ & 359 & 34 & 1.1 & $(0.6,2.0)$ & 0.83 \\
\hline & $60-79$ & 478 & 86 & 1.6 & $(0.9,2.9)$ & 0.11 \\
\hline & $\geq 80$ & 409 & 64 & 1.3 & $(0.7,2.3)$ & 0.44 \\
\hline \multirow[t]{2}{*}{ Gender } & male & 707 & 82 & 1 & & \\
\hline & female & 769 & 121 & 1.6 & $(1.2,2.3)$ & $<0.01$ \\
\hline \multirow[t]{2}{*}{ Vomiting } & no & 1304 & 169 & 1 & & \\
\hline & yes & 172 & 34 & 1.7 & $(1.1,2.6)$ & 0.02 \\
\hline \multirow[t]{2}{*}{ Lethargy } & no & 1300 & 168 & 1 & & \\
\hline & yes & 176 & 35 & 1.3 & $(0.9,2.0)$ & 0.19 \\
\hline \multirow[t]{2}{*}{ Muscle weakness } & no & 1368 & 178 & 1 & & \\
\hline & yes & 108 & 25 & 1.6 & $(1.0,2.7)$ & 0.05 \\
\hline \multirow[t]{2}{*}{ Polyuria } & no & 1472 & 199 & 1 & & \\
\hline & yes & 4 & 4 & 9.7 & $(2.2,44.0)$ & $<0.01$ \\
\hline \multirow[t]{2}{*}{ Confusion } & no & 1372 & 172 & 1 & & \\
\hline & yes & 104 & 31 & 2.3 & $(1.4,3.6)$ & $<0.01$ \\
\hline \multirow[t]{2}{*}{ Palpitations } & no & 1297 & 190 & 1 & & \\
\hline & yes & 179 & 13 & 0.8 & $(0.4,1.4)$ & 0.44 \\
\hline \multirow[t]{2}{*}{ Paraesthesia } & no & 1426 & 201 & 1 & & \\
\hline & yes & 50 & 2 & 0.3 & $(0.1,1.5)$ & 0.16 \\
\hline \multirow[t]{2}{*}{ Proton pump inhibitor } & no & 992 & 118 & 1 & & \\
\hline & yes & 484 & 85 & 1.0 & $(0.7,1.4)$ & 0.96 \\
\hline \multirow[t]{2}{*}{ Vitamin D } & no & 1112 & 128 & 1 & & \\
\hline & yes & 364 & 75 & 1.3 & $(0.9,1.8)$ & 0.14 \\
\hline \multirow[t]{2}{*}{ Insulin } & no & 1378 & 181 & 1 & & \\
\hline & yes & 98 & 22 & 0.9 & $(0.5,1.7)$ & 0.76 \\
\hline \multirow[t]{2}{*}{ Beta agonist } & no & 1341 & 172 & 1 & & \\
\hline & yes & 135 & 31 & 1.5 & $(1.0,2.4)$ & 0.06 \\
\hline \multirow[t]{2}{*}{ Phosphate supplements } & no & 1469 & 200 & 1 & & \\
\hline & yes & 7 & 3 & 3.0 & $(0.7,12.7)$ & 0.14 \\
\hline \multirow[t]{2}{*}{ Chronic kidney disease } & no & 1308 & 164 & 1 & & \\
\hline & yes & 168 & 39 & 1.3 & $(0.8,2.0)$ & 0.24 \\
\hline Hyperparathyroidism & no & 1469 & 198 & 1 & & \\
\hline
\end{tabular}




\begin{tabular}{llccrcc} 
& yes & 7 & 5 & 4.3 & $(1.3,15.1)$ & 0.02 \\
Cancer & no & 1129 & 128 & 1 & & \\
& yes & 347 & 75 & 1.7 & $(1.2,2.4)$ & $<0.01$ \\
Hypothyroidism & no & 1396 & 198 & 1 & & \\
& yes & 80 & 5 & 0.4 & $(0.1,0.95)$ & 0.04 \\
Type 1 diabetes & no & 1462 & 197 & 1 & & \\
Type 2 diabetes & yes & 14 & 6 & 3.6 & $(1.1,11.9)$ & 0.04 \\
& no & 1206 & 148 & 1 & & \\
& yes & 270 & 55 & 1.4 & $(0.9,2.1)$ & 0.09 \\
\hline
\end{tabular}

Table 3. Logistic regression results: Variables associated with a low magnesium level

\begin{tabular}{|c|c|c|c|c|c|c|}
\hline \multirow{2}{*}{ risk variable } & & \multicolumn{2}{|c|}{$\begin{array}{c}\text { magnesium level } \\
\text { low }(n=1576)\end{array}$} & \multirow[b]{2}{*}{ OR } & \multirow[b]{2}{*}{$(95 \% \mathrm{CI})$} & \multirow[b]{2}{*}{$\mathrm{p}$} \\
\hline & & no & yes & & & \\
\hline \multirow[t]{4}{*}{ Age, years } & $18-39$ & 230 & 10 & 1 & & \\
\hline & $40-59$ & 350 & 19 & 0.9 & $(0.4,2.3)$ & 0.88 \\
\hline & $60-79$ & 469 & 59 & 2.0 & $(0.9,4.6)$ & 0.10 \\
\hline & $\geq 80$ & 399 & 40 & 1.8 & $(0.8,4.4)$ & 0.17 \\
\hline \multirow[t]{2}{*}{ Gender } & male & 702 & 49 & 1 & & \\
\hline & female & 746 & 79 & 1.9 & $(1.3,3.0)$ & $<0.01$ \\
\hline \multirow[t]{2}{*}{ Nausea } & no & 1253 & 99 & 1 & & \\
\hline & yes & 195 & 29 & 1.5 & $(0.9,2.5)$ & 0.15 \\
\hline \multirow[t]{2}{*}{ Vomiting } & no & 1279 & 106 & 1 & & \\
\hline & yes & 169 & 22 & 1.3 & $(0.7,2.3)$ & 0.40 \\
\hline \multirow[t]{2}{*}{ Lethargy } & no & 1281 & 105 & 1 & & \\
\hline & yes & 167 & 23 & 1.2 & $(0.7,2.1)$ & 0.51 \\
\hline \multirow[t]{2}{*}{ Palpitations } & no & 1252 & 120 & 1 & & \\
\hline & yes & 196 & 8 & 0.9 & $(0.4,2.0)$ & 0.83 \\
\hline \multirow[t]{2}{*}{ Diarrhoea } & no & 1373 & 110 & 1 & & \\
\hline & yes & 75 & 18 & 1.8 & $(0.9,3.8)$ & 0.10 \\
\hline \multirow[t]{2}{*}{ Diuretics } & no & 1122 & 85 & 1 & & \\
\hline & yes & 326 & 43 & 0.8 & $(0.5,1.3)$ & 0.34 \\
\hline \multirow[t]{2}{*}{ Proton pump inhibitor } & no & 1002 & 51 & 1 & & \\
\hline & yes & 446 & 77 & 2.2 & $(1.4,3.3)$ & $<0.01$ \\
\hline \multirow[t]{2}{*}{ Vitamin D } & no & 1090 & 76 & 1 & & \\
\hline & yes & 358 & 52 & 1.2 & $(0.8,2.0)$ & 0.40 \\
\hline \multirow[t]{2}{*}{$\mathrm{ARB}$} & no & 1225 & 100 & 1 & & \\
\hline & yes & 223 & 28 & 1.2 & $(0.7,2.0)$ & 0.58 \\
\hline \multirow[t]{2}{*}{ ACE inhibitor } & no & 1264 & 103 & 1 & & \\
\hline & yes & 184 & 25 & 1.4 & $(0.8,2.4)$ & 0.23 \\
\hline
\end{tabular}




\begin{tabular}{|c|c|c|c|c|c|c|}
\hline \multirow[t]{2}{*}{ Beta agonist } & no & 1315 & 106 & 1 & & \\
\hline & yes & 133 & 22 & 1.7 & $(1.0,3.0)$ & 0.06 \\
\hline \multirow[t]{2}{*}{ Calcium supplement } & no & 1332 & 103 & 1 & & \\
\hline & yes & 116 & 25 & 1.5 & $(0.8,2.7)$ & 0.22 \\
\hline \multirow[t]{2}{*}{ Magnesium supplement } & no & 1339 & 110 & 1 & & \\
\hline & yes & 109 & 18 & 0.7 & $(0.3,1.3)$ & 0.24 \\
\hline \multirow[t]{2}{*}{ Glucocorticoid } & no & 1324 & 109 & 1 & & \\
\hline & yes & 124 & 19 & 0.9 & $(0.4,1.7)$ & 0.71 \\
\hline \multirow[t]{2}{*}{ Digoxin } & no & 1415 & 120 & 1 & & \\
\hline & yes & 33 & 8 & 1.7 & $(0.7,4.4)$ & 0.23 \\
\hline \multirow[t]{2}{*}{ Tacrolimus } & no & 1434 & 118 & 1 & & \\
\hline & yes & 14 & 10 & 13.1 & $(4.1,41.3)$ & $<0.01$ \\
\hline \multirow[t]{2}{*}{ Chemotherapy } & no & 1420 & 122 & 1 & & \\
\hline & yes & 28 & 6 & 2.0 & $(0.7,5.9)$ & 0.19 \\
\hline \multirow[t]{2}{*}{ Chronic kidney disease } & no & 1277 & 106 & 1 & & \\
\hline & yes & 171 & 22 & 0.6 & $(0.4,1.1)$ & 0.13 \\
\hline \multirow[t]{2}{*}{ Cancer } & no & 1114 & 88 & 1 & & \\
\hline & yes & 334 & 40 & 1.6 & $(1.0,2.6)$ & 0.05 \\
\hline \multirow[t]{2}{*}{ Pancreatitis } & no & 1436 & 123 & 1 & & \\
\hline & yes & 12 & 5 & 0.9 & $(0.2,3.8)$ & 0.84 \\
\hline \multirow[t]{2}{*}{ Pancreatic insufficiency } & no & 1443 & 125 & 1 & & \\
\hline & yes & 5 & 3 & 4.4 & $(0.7,25.6)$ & 0.10 \\
\hline \multirow[t]{2}{*}{ Diarrhoea } & no & 1427 & 121 & 1 & & \\
\hline & yes & 21 & 7 & 3.1 & $(1.0,10.0)$ & 0.05 \\
\hline \multirow[t]{2}{*}{ Chronic liver disease } & no & 1415 & 118 & 1 & & \\
\hline & yes & 33 & 10 & 0.9 & $(0.3,2.6)$ & 0.92 \\
\hline \multirow[t]{2}{*}{ Alcohol abuse } & no & 1388 & 105 & 1 & & \\
\hline & yes & 60 & 23 & 9.3 & $(4.6,19.1)$ & $<0.01$ \\
\hline \multirow[t]{2}{*}{ Type 2 diabetes } & no & 1193 & 76 & 1 & & \\
\hline & yes & 255 & 52 & 2.9 & $(1.9,4.7)$ & $<0.01$ \\
\hline
\end{tabular}


Table 4. Logistic regression results: Variables associated with a high magnesium level

\begin{tabular}{|c|c|c|c|c|c|c|}
\hline \multirow[b]{2}{*}{ risk variable } & & \multicolumn{2}{|c|}{$\begin{array}{c}\text { magnesium level } \\
\text { high }(n=1576)\end{array}$} & \multirow[b]{2}{*}{ OR } & \multirow[b]{2}{*}{$(95 \% \mathrm{CI})$} & \multirow[b]{2}{*}{$\mathrm{p}$} \\
\hline & & no & yes & & & \\
\hline \multirow[t]{2}{*}{ Gender } & male & 729 & 22 & 1 & & \\
\hline & female & 817 & 8 & 0.4 & $(0.2,1.0)$ & 0.04 \\
\hline \multirow[t]{2}{*}{ Lethargy } & no & 1366 & 20 & 1 & & \\
\hline & yes & 180 & 10 & 4.3 & $(1.7,10.7)$ & $<0.01$ \\
\hline \multirow[t]{2}{*}{ Diuretics } & no & 1192 & 15 & 1 & & \\
\hline & yes & 354 & 15 & 1.3 & $(0.5,3.7)$ & 0.56 \\
\hline \multirow[t]{2}{*}{ Furosemide } & no & 1420 & 23 & 1 & & \\
\hline & yes & 126 & 7 & 1.6 & $(0.5,5.3)$ & 0.40 \\
\hline \multirow[t]{2}{*}{ Thiazide } & no & 1510 & 26 & 1 & & \\
\hline & yes & 36 & 4 & 4.5 & $(1.1,18.4)$ & 0.03 \\
\hline \multirow[t]{2}{*}{ Vitamin D } & no & 1151 & 15 & 1 & & \\
\hline & yes & 395 & 15 & 1.4 & $(0.6,3.5)$ & 0.48 \\
\hline \multirow[t]{2}{*}{ Insulin } & no & 1436 & 24 & 1 & & \\
\hline & yes & 110 & 6 & 1.0 & $(0.3,3.5)$ & 0.94 \\
\hline
\end{tabular}


Calcium, magnesium and phosphate testing

\begin{tabular}{|c|c|c|c|c|c|c|}
\hline \multirow[t]{2}{*}{ Calcium supplement } & no & 1411 & 24 & 1 & & \\
\hline & yes & 135 & 6 & 1.3 & $(0.4,4.3)$ & 0.69 \\
\hline \multirow[t]{2}{*}{ Lithium } & no & 1540 & 29 & 1 & & \\
\hline & yes & 6 & 1 & 7.9 & $(0.4,160.0)$ & 0.18 \\
\hline \multirow[t]{2}{*}{ Bisphosphonate } & no & 1501 & 27 & 1 & & \\
\hline & yes & 45 & 3 & 2.0 & $(0.4,8.8)$ & 0.37 \\
\hline \multirow[t]{2}{*}{ Phosphate binders } & no & 1533 & 27 & 1 & & \\
\hline & yes & 13 & 3 & 3.5 & $(0.6,20.3)$ & 0.16 \\
\hline \multirow[t]{2}{*}{ Chronic kidney disease } & no & 1367 & 16 & 1 & & \\
\hline & yes & 179 & 14 & 4.5 & $(1.7,12.1)$ & $<0.01$ \\
\hline \multirow[t]{2}{*}{ Diabetes type 2} & no & 1251 & 18 & 1 & & \\
\hline & yes & 295 & 12 & 1.3 & $(0.5,3.6)$ & 0.55 \\
\hline
\end{tabular}

Table 5. Logistic regression results: Variables associated with a low phosphate level

\begin{tabular}{|c|c|c|c|c|c|c|}
\hline \multirow[b]{2}{*}{ risk variable } & & \multicolumn{2}{|c|}{$\begin{array}{c}\text { phosphate level } \\
\text { low }(n=1511)\end{array}$} & \multirow[b]{2}{*}{ OR } & \multirow[b]{2}{*}{$(95 \% \mathrm{CI})$} & \multirow[b]{2}{*}{$\mathrm{p}$} \\
\hline & & no & yes & & & \\
\hline \multirow[t]{2}{*}{ Gender } & male & 600 & 121 & 1 & & \\
\hline & female & 687 & 103 & 0.7 & $(0.5,0.9)$ & 0.02 \\
\hline \multirow[t]{2}{*}{ Nausea } & no & 1115 & 177 & 1 & & \\
\hline & yes & 172 & 47 & 1.7 & $(1.1,2.6)$ & $<0.01$ \\
\hline \multirow[t]{2}{*}{ Vomiting } & no & 1140 & 186 & 1 & & \\
\hline & yes & 147 & 38 & 1.3 & $(0.9,2.1)$ & 0.18 \\
\hline \multirow[t]{2}{*}{ Confusion } & no & 1196 & 200 & 1 & & \\
\hline & yes & 91 & 24 & 1.6 & $(1.0,2.6)$ & 0.06 \\
\hline
\end{tabular}




\begin{tabular}{|c|c|c|c|c|c|c|}
\hline \multirow[t]{2}{*}{ Seizure } & no & 1236 & 206 & 1 & & \\
\hline & yes & 51 & 69 & 2.1 & $(1.2,3.8)$ & 0.01 \\
\hline \multirow[t]{2}{*}{ Diuretics } & no & 965 & 186 & 1 & & \\
\hline & yes & 322 & 38 & 0.6 & $(0.4,0.9)$ & 0.01 \\
\hline \multirow[t]{2}{*}{ Phosphate supplements } & no & 1282 & 221 & 1 & & \\
\hline & yes & 5 & 3 & 2.5 & $(0.5,11.9)$ & 0.26 \\
\hline \multirow[t]{2}{*}{ Antacids } & no & 1275 & 218 & 1 & & \\
\hline & yes & 12 & 6 & 2.3 & $(0.8,6.6)$ & 0.12 \\
\hline \multirow[t]{2}{*}{ Glucocorticoids } & no & 1182 & 189 & 1 & & \\
\hline & yes & 105 & 35 & 1.7 & $(1.1,2.7)$ & 0.02 \\
\hline \multirow[t]{2}{*}{ Tacrolimus } & no & 1272 & 215 & 1 & & \\
\hline & yes & 15 & 9 & 2.4 & $(1.0,6.2)$ & 0.06 \\
\hline \multirow[t]{2}{*}{ Chronic kidney disease } & no & 1125 & 198 & 1 & & \\
\hline & yes & 162 & 26 & 1.6 & $(0.8,3.4)$ & 0.21 \\
\hline
\end{tabular}

Table 6. Logistic regression results: Variables associated with a high phosphate level

\begin{tabular}{llccrrrr} 
& \multicolumn{4}{c}{ phosphate level } & & & \\
& & \multicolumn{2}{c}{ high $(\mathrm{n}=1511)$} & & & \\
\cline { 3 - 4 } & no & yes & & OR & $(95 \% \mathrm{CI})$ & p \\
\hline Polyuria & 1343 & 160 & & 1 & & \\
& yes & 5 & 3 & & 5.0 & $(1.1,23.6)$ & 0.04
\end{tabular}




\begin{tabular}{|c|c|c|c|c|c|c|}
\hline \multirow[t]{2}{*}{ Hand or foot spasm } & no & 1344 & 161 & 1 & & \\
\hline & yes & 4 & 2 & 5.1 & $(0.8,32.1)$ & 0.08 \\
\hline \multirow[t]{2}{*}{ Confusion } & no & 1240 & 156 & 1 & & \\
\hline & yes & 108 & 7 & 0.5 & $(0.2,1.0)$ & 0.07 \\
\hline \multirow[t]{2}{*}{ Palpitations } & no & 1171 & 156 & 1 & & \\
\hline & yes & 177 & 7 & 0.4 & $(0.2,0.9)$ & 0.03 \\
\hline \multirow[t]{2}{*}{ Diuretics } & no & 1054 & 97 & 1 & & \\
\hline & yes & 294 & 66 & 1.9 & $(1.2,3.0)$ & $<0.01$ \\
\hline \multirow[t]{2}{*}{ Furosemide } & no & 1241 & 140 & 1 & & \\
\hline & yes & 107 & 23 & 0.8 & $(0.4,1.5)$ & 0.43 \\
\hline \multirow[t]{2}{*}{ Thiazides } & no & 1318 & 155 & 1 & & \\
\hline & yes & 30 & 8 & 1.6 & $(0.6,3.9)$ & 0.34 \\
\hline \multirow[t]{2}{*}{ Vitamin D } & no & 1019 & 96 & 1 & & \\
\hline & yes & 329 & 67 & 1.4 & $(0.9,2.2)$ & 0.09 \\
\hline \multirow[t]{2}{*}{ Insulin } & no & 1257 & 141 & 1 & & \\
\hline & yes & 91 & 22 & 0.8 & $(0.4,1.7)$ & 0.61 \\
\hline \multirow[t]{2}{*}{ Calcium supplement } & no & 1236 & 138 & 1 & & \\
\hline & yes & 112 & 25 & 1.1 & $(0.6,1.9)$ & 0.78 \\
\hline \multirow[t]{2}{*}{ Digoxin } & no & 1310 & 162 & 1 & & \\
\hline & yes & 38 & 1 & 0.1 & $(0.01,1.0)$ & 0.06 \\
\hline \multirow[t]{2}{*}{ Cyclosporine } & no & 1343 & 159 & 1 & & \\
\hline & yes & 5 & 4 & 4.1 & $(1.0,17.0)$ & 0.06 \\
\hline \multirow[t]{2}{*}{ Phosphate binders } & no & 1339 & 157 & 1 & & \\
\hline & yes & 9 & 6 & 1.8 & $(0.6,6.0)$ & 0.32 \\
\hline \multirow[t]{2}{*}{ Chronic kidney disease } & no & 1213 & 110 & 1 & & \\
\hline & yes & 135 & 53 & 3.5 & $(2.2,5.4)$ & $<0.001$ \\
\hline \multirow[t]{2}{*}{ Hypothyroidism } & no & 1284 & 148 & 1 & & \\
\hline & yes & 64 & 15 & 1.9 & $(1.0,3.6)$ & 0.06 \\
\hline \multirow[t]{2}{*}{ Type 1 diabetes } & no & 1336 & 156 & 1 & & \\
\hline & yes & 12 & 7 & 3.5 & $(1.0,12.4)$ & 0.06 \\
\hline \multirow[t]{2}{*}{ Type 2 diabetes } & no & 1094 & 119 & 1 & & \\
\hline & yes & 254 & 44 & 1.1 & $(0.7,1.7)$ & 0.81 \\
\hline
\end{tabular}


Box. Important risk variables for calcium, magnesium or phosphate abnormalities

\begin{tabular}{|lll|}
\hline calcium & magnesium & phosphate \\
$\begin{array}{l}\text { Medical History } \\
\text { Ca or } \mathrm{PO}_{4} \text { supplements } \\
\text { hyperparathyroidism } \\
\text { chemotherapy } \\
\text { type } 1 \text { diabetes } \\
\text { cancer }\end{array}$ & $\begin{array}{l}\text { tacrolimus } \\
\text { alcohol abuse } \\
\text { thiazide diuretics } \\
\text { chronic kidney disease } \\
\text { type 2 diabetes } \\
\text { proton pump inhibitor }\end{array}$ & $\begin{array}{l}\text { chronic kidney disease } \\
\text { diuretics } \\
\text { glucocorticoids }\end{array}$ \\
$\begin{array}{l}\text { Signs and Symptoms } \\
\begin{array}{l}\text { perioral numbness } \\
\text { hand or foot spasm } \\
\text { polyuria }\end{array}\end{array}$ & \\
$\begin{array}{l}\text { vomiting } \\
\text { confusion }\end{array}$ & lethargy & $\begin{array}{l}\text { polyuria } \\
\text { seizures } \\
\text { nausea }\end{array}$ \\
\hline
\end{tabular}

Ca calcium, $\mathrm{PO}_{4}$ phosphate 


\section{University Library}

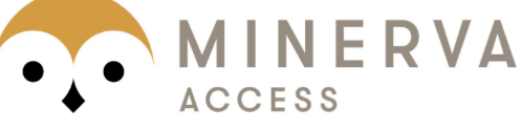

A gateway to Melbourne's research publications

Minerva Access is the Institutional Repository of The University of Melbourne

Author/s:

Taylor, DM;Date, PA;Ugoni, A;Smith, JL;Spencer, WS;de Tonnerre, EJ;Yeoh, MJ

Title:

Risk variables associated with abnormal calcium, magnesium and phosphate levels among emergency department patients

Date:

2019-12-17

Citation:

Taylor, D. M., Date, P. A., Ugoni, A., Smith, J. L., Spencer, W. S., de Tonnerre, E. J. \& Yeoh, M. J. (2019). Risk variables associated with abnormal calcium, magnesium and phosphate levels among emergency department patients. EMERGENCY MEDICINE AUSTRALASIA, 32 (2), pp.303-312. https://doi.org/10.1111/1742-6723.13411.

Persistent Link:

http://hdl.handle.net/11343/286755 